\title{
TTR
}

Traduction, terminologie, rédaction

\section{Norman Cheadle and Lucien Pelletier, eds. Canadian Cultural Exchange: Translation and Transculturation/Échanges culturels au Canada: Traduction et transculturation. Waterloo, Wilfred Laurier University Press, 2007, 432 p.}

\section{Christel Kopp}

Volume 24, numéro 2, 2e semestre 2011

URI : https://id.erudit.org/iderudit/1013401ar

DOI : https://doi.org/10.7202/1013401ar

Aller au sommaire du numéro

Éditeur(s)

Association canadienne de traductologie

ISSN

0835-8443 (imprimé)

1708-2188 (numérique)

Découvrir la revue

Citer ce compte rendu

Kopp, C. (2011). Compte rendu de [Norman Cheadle and Lucien Pelletier, eds. Canadian Cultural Exchange: Translation and Transculturation/Échanges culturels au Canada: Traduction et transculturation. Waterloo, Wilfred Laurier University Press, 2007, 432 p.] TTR, 24(2), 231-234.

https://doi.org/10.7202/1013401ar d'utilisation que vous pouvez consulter en ligne. 


\section{COMPTES RENDUS}

Norman Cheadle and Lucien Pelletier, eds. Canadian Cultural Exchange: Translation and Transculturation/Échanges culturels au Canada : Traduction et transculturation. Waterloo, Wilfred Laurier University Press, 2007, 432 p.

This book cannot be made to fit into a given mould any more than the characters, real or fictional, that inhabit its pages. The bold orange and blue cover, based on the painting ;Bailamos! by Michel Galipeau, entices us into a patchwork of articles by specialists from various academic areas who analyze the past and present cultural exchanges that make up the fabric of Canada. The cross-cultural elements in question are almost exclusively linked to authors and literary texts, and the seventeen contributions (plus the appendix) revolve around the key notions of "transculturation" (a term coined by Fernando Ortiz and discussed in several articles) and of "translation" at the social, textual and personal levels. The cases examined in the book's chapters range from cultural appropriation to translational appropriation to reappropriation and highlight very positive aspects of the often maligned concept of "appropriation." The seventeen contributions are organized according to five themes, roughly speaking: Canada's past, cultural appropriation (good or bad?), transculturation embodied in Canada, two solitudes plus, and Canada's future. In addition, there are several other themes that cut across these divisions.

The Spanish title of the cover illustration anticipates what proves to be one of the most prevalent cultural presences in the book: Latin America. At the social level, Victor Armony examines "La 'latinité' des Québécois à l'épreuve" in an attempt to define the characteristics that make up a "Latin" culture and to determine if Quebec shares these characteristics to a significant extent with Latin America. At the textual level, in "I Write My Self: The Female Body as a Site of Transculturation in the Short Stories of Carmen Rodríguez," Carol Stos compares Carmen Rodríguez's "transcreated" Spanish and English versions of essentially the same collection of short stories (De Cuerpo Entero and and a body to remember with) and the reasoning behind her cultural adjustments. And at the personal level, Neil Besner's essay, 
"Translating North and South: Elizabeth Bishop, Biography and Brazil," looks at the figure of American ${ }^{1}$ poet Elizabeth Bishop, the difficulties of her "personal translation" into a Brazilian context, and the translation of her biography back into English.

The Indigenous and Métis presence in Canada marks another major cultural identity examined in the collection from both a historical and contemporary point of view. In an historical vein, Alexandra Klinge and Alan MacDonell's article, "La voix de l'Autre dans certains récits de voyages de l'Ouest canadien au temps de la Nouvelle-France," tells us about the indigenous voice in explorer La Vérandrye's journals and its role in the justification of the colonial agenda. Albert Braz's article "The Creative Translator: Textual Additions and Deletions in A Martyr's Folly" compares the strategic and possibly politically-motivated differences between two anonymous translations of a novel based on the life of Louis Riel. A study of a more contemporary event, Beverley Curran's “Dry Lips Moves to Tokyo: Does Indigenous Drama Translate?" discusses the recent staging of the play by Tomson Highway in Japan and the issues involved in the work's migration to another linguistic and cultural milieu with its own indigenous peoples. More metaphorically, Laurence Steven's “Transculturation in George Elliott Clarke's Whylah Falls: Or, When Is It Appropriate to Appropriate?" argues for the interpretation of métissage as the cultural quilt that makes up this author's poetic style and the gumbo that constitutes the Canadian identity.

Exile and migration are classic representations of crosscultural transfers. Lucien Pelletier's interview with poet Robert Dickson, "La migration culturelle de Robert Dickson," illustrates how cultural migration is independent of distance. Dickson, to whose memory the book is dedicated (see p. xxi), experienced the process of "cultural migration" when he left his Anglophone roots in Erin, Ontario, to start a new Francophone life in Sudbury, Ontario. In addition to Dickson's importance as a poet, the article

1 Mistakenly described in the introduction as "Canadian-born" (p. $\mathrm{x}$ ), Bishop was born in the US. However, she spent part of her childhood in Nova Scotia. 
discusses his translation of, and meeting with, Lola Lemire Tostevin, whose cultural migration was in the reverse direction, and who was profoundly moved by Dickson's translation of her work. Migration can also take place geographically over long distances, as in the case of Arthur Nortje, a South African author (by birth) reclaimed as Canadian in "Repatriating Arthur Nortje" by George Elliott Clarke, who in turn represents an additional significant cultural group discussed in the collection, the Africadians. Another recurrent theme is exile: according to José Antonio Giménez Micó ("Latin-Americanizing Canada"), "the writings of Latin American exiles [,] who have settled in Canada and contributed to the reshaping of a Canadian identity that is more aware of its own diversity" (p. 59), have afforded a means for these authors to deal with the pain involved in their traumatic experience of emigration and immigration.

The conundrum faced by immigrant authors is also examined in Stephen Henighan's "A Reduced Solitude: Eugen Giurgiu's Ewoclem sau intortocheatele cărări [Ewoclem, or The Twisted Paths] as Romanian-Canadian Literature." The argument is that Canadian authors writing in a language other than English or French, Romanian for example, face the problem of establishing a target audience. When they write in their mother tongue, their writings are disconnected (1) from the readership of their country of origin (despite their common language) because of the way life has changed in their country of origin since their departure; and (2) from the readership of their country of residence because of a difference in language, literary background, and past experiences. As if in response to this problematic situation, the following essay, Hugh Hazelton's “Polylingual Identities: Writing in Multiple Languages," discusses the solution adopted by many Hispanic-Canadian authors who write bilingual or polylingual works in order to "bridge the divergence and isolation created by different languages" (p. 236). Works such as these address, and help generate, a bilingual or even trilingual readership.

Thus the aspects of transculturation discussed in the different chapters can be seen not only in the content of the articles but also in the bilingual character of the anthology: the double title, the fact that the articles are in both French (four in number) 
and English (thirteen), and the complementary editorial voices of Norman Cheadle, who wrote the introduction in English, and Lucien Pelletier, who wrote the postface in French. Cheadle's comments in particular prepare us for possible criticisms that could be levelled at this interesting collection. First, Cheadle's disclaimer that the work is not representative of all the possible "cultural productions in Canada" (p. xiv) warns the reader not to expect an exhaustive overview of Canadian multiculturalism and, indeed, many more elements of the Canadian mosaic could have been discussed. However, in fairness to the book's editors, is it reasonable to expect that a single collection cover all aspects of Canadian multiculturalism? Second, Cheadle expects that the reader will find that many themes overlap and can be freely rearranged. This reader, for one, rather liked the ongoing conversation among the many participating voices, the back-and-forth discussion of the several themes that run through the collection, resulting from the overlap. Third, in an apologetic manner, Cheadle prepares the reader for the fact that the collection includes a variety of disciplines and discursive practices (p. xv). But variety makes for interesting reading. Finally, Cheadle makes another cautionary remark regarding the one translation in the collection: he states that Kate Alvo's English translation of Giménez Micós article written originally in Spanish, is "opaque" (p. xv) and defends this quality. I cannot say that I noticed anything "opaque" in the text. If "opaque" is to be likened to "foreignizing," then many readers will consider this a virtue and quite in keeping with the lessons to be learned from a book on transculturality. In the end, the anticipated criticisms seem more to reflect the positive qualities of a stimulating and timely collection that whets the reader's appetite for more essays on our transcultural Canada.

Christel Kopp UNIVERSITY OF OTtaWA 